Journal of Asian Scientific Research

$\operatorname{ISSN}(e): \quad 2223-1331$

$\operatorname{ISSN}(p): \quad 2226-5724$

DOI: 10.18488/journal.2.2021.112.15.24

Vol. 11, No. 2, 15-24.

(C) 2021 AESS Publications. All Rights Reserved.

URL: wrww.aessweb.com

\title{
EVALUATION AND PERFORMANCE OF ACTIVATED SLUDGE HI- KLEEN TREATMENT PLANT (ASHTP): A CASE STUDY
}

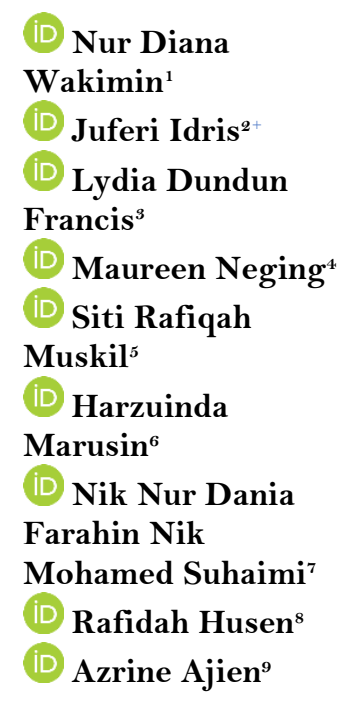

Article History

Received: 20 July 2021 Revised: 18 August 2021 Accepted: 6 September 2021 Published: 22 September 2021

\section{Keywords}

Activated sludge

Hi-Kleen treatment plant

Sewage treatment plant

Total suspended solids

Chemical oxygen demand

Turbidity.

\author{
${ }_{1,2,9,5,5,6,7,9}$ Faculty of Chemical Engineering, College of Engineering, Universiti \\ Teknologi MARA (UiTM), Sarawak Branch, Samarahan Campus, \\ Sarawak, Malaysia. \\ 'Email:nurdiana@uitm.edu.my Tel:+60133690172 \\ EEmail:juferi@uitm.edu.my Tel:+60128927419 \\ ${ }^{s}$ Email: lydiafrancis@uitm.edu.my Tel:+60163536978 \\ ${ }^{5}$ Email: iraf5829@gmail.com Tel: +601114064169 \\ ${ }^{6}$ Email:harzuindamarusin@gmail.com Tel:+601151786826 \\ "Email: daniafarahin@gmail.com Tel : +601115232238 \\ ${ }^{9}$ Email: azrineajien2@gmail.com Tel : +601135076500 \\ ${ }^{4}$ Faculty of Civil Engineering, College of Engineering, Universiti Teknologi \\ MARA (UiTM), Sarawak Branch, Samarahan 2 Campus, Sarawak, \\ Malaysia. \\ ${ }^{4}$ Email: maureenneging@uitm.edu.my Tel:+60198881695 \\ ${ }^{8}$ Faculty of Applied Sciences, Universiti Teknologi MARA (UiTM), \\ Sarawak Branch, Samarahan 2 Campus, Sarawak, Malaysia. \\ ${ }^{8}$ Email: rafidahh@uitm.edu.my Tel: +60198780478
}

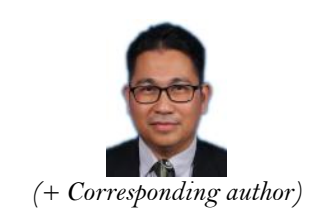

\section{ABSTRACT}

Pollutants from sewage wastewater are major concerns due to their environmental effects. Thus, an effective sewage wastewater treatment plant is important to ensure discharged effluent is well treated before it can be released to rivers or water streams. This study aims to evaluate the performance of the Activated Sludge Hi-Kleen Treatment Plant (ASHTP) located at H Block (ASHTP at H Block) and L Block (ASHTP at L Block) in UiTM Sarawak Branch, Samarahan Campus, Sarawak, Malaysia. The evaluation was based on physicochemical and removal efficiency namely $\mathrm{pH}$, temperature, turbidity, chemical oxygen demand (COD), and total suspended solids (TSS) from raw influent and treated effluent. The findings indicated that the overall performance of both ASHTP at H Block and L Block were satisfactory where treated effluent meets the standard discharge limits of Environmental Quality (Sewage) Regulations 2009 (Standard B). For ASHTP at H Block, the removal efficiencies of turbidity, COD, and TSS were found to be $86.00,13.76$, and $88.02 \%$ respectively, in which the $\mathrm{pH}$, temperature, turbidity, COD, and TSS of the treated effluent were 7.30, $28.10^{\circ} \mathrm{C}, 10.40 \mathrm{NTU}, 14.10 \mathrm{mg} / \mathrm{L}$ and $8.90 \mathrm{mg} / \mathrm{L}$ respectively. Meanwhile, for ASHTP at L Block, the removal efficiencies of turbidity, COD, and TSS were found to be 43.20, 41.90 , and $51.61 \%$ respectively, in which the $\mathrm{pH}$, temperature, turbidity, COD, and TSS in the treated effluent were $7.30,27.90^{\circ} \mathrm{C}, 21.10 \mathrm{NTU}, 58.10 \mathrm{mg} / \mathrm{L}$ and $18.00 \mathrm{mg} / \mathrm{L}$ respectively. Proper maintenance of sewage treatment plant is important to ensure its effectiveness as well as to prolong its lifespan. 
Contribution/ Originality: This study contributes to the existing literature about the evaluation and performance of the Activated Sludge Hi-Kleen Treatment Plant (ASHTP). The findings of this study are beneficial for the plant operator to achieve optimum operation of the system to ensure full compliance with the standards and preserving the environment.

\section{INTRODUCTION}

As the human population and urbanization increase, demand for clean water is crucial, especially in urban areas. Discharge of wastewater particularly from domestic sewage wastewater is one of the challenges in providing a clean water supply. Pollutant from domestic sewage wastewater has high impurities including organic and inorganic materials, suspended and dissolved solids and microorganisms [1]. Untreated sewage wastewater discharged to water resources is harmful to the water ecosystem as it causes detrimental effects on human health that could be carried by water-borne diseases. Therefore, a proper sewage treatment process to treat the wastewater must be made available to reduce the negative impacts on human health and the environment caused by the discharge of untreated wastewater.

Sewage treatment plant is designed to treat sewage wastewater so that the physicochemical properties of the treated sewage wastewater meet the water quality standards set by the legislative board before it can be discharged to the environment [2]. During the treatment process, the sewage wastewater system produces a solid residue known as sewage sludge; a complex solid by-product which accounts for half of the capital cost in establishing the sewage wastewater treatment plant [3]. Solid waste management in the wastewater treatment process is carried out by processing the sludge before it can be directly disposed of or undergo a thermochemical process to be converted into valuable products for environmental application [4,5].

One of the available sewage wastewater treatment plants to remove contaminants from sewage wastewater is the Activated Sludge Hi-Kleen Treatment Plant (ASHTP). One of the existing ASHTP is currently used by Universiti Teknologi MARA Sarawak Branch, Samarahan Campus, Sarawak, Malaysia, which has $31-5000$ populations equivalent (PE). It has been operating for more than 20 years. There are two (2) units of ASHTP established on the campus; one is located at H Block area named ASHTP at H Block, while the other one is located at L Block area named ASHTP at L Block. ASHTP was established as a sewage wastewater treatment plant on the campus due to its simple design, fast installation, low operation and maintenance cost with small land area requirement. The sewage wastewater treatment process by ASHTP consists of four main stages namely, (1) screening, (2) equalization, (3) aeration, and (4) sedimentation. In the first stage, screening involves the removal of large objects which cause blockage and damage to the equipment during the wastewater treatment process. Removal of grit which travels along the flow of the sewage wastewater is also carried out during this stage. [6]. In the second stage, which is the equalization stage, the flow rate or hydraulic velocity of the influent is controlled by an equalizer [7]. In the third stage, aeration involves the application of air or oxygen to reduce solid organic matter content by treating the wastewater in oxygen-rich conditions [8]. The reduction of solid organic matter content is aided by bacteria which plays a vital role in consuming the contaminants in the wastewater [3,9]. In the final stage, sedimentation involves the settlement of the remaining solid organic matter in the wastewater, whereby the organic matter is pulled down by gravitational force and is settled down on the bottom surface of the tank as sediments [10]. These sediments are now known as sludge, which is mainly processed under aerobic or anaerobic digestion [11].

The performance of ASHTP as a sewage treatment plant is measured by evaluating the effluent quality which must comply with the Environmental Quality (Sewage) Regulations 2009 under Environmental Quality Act (EQA) 1974 [12]. In the evaluation of the effluent quality, sewage wastewater parameters including $\mathrm{pH}$, temperature, turbidity, chemical oxygen demands (COD), and total suspended solids (TSS) are measured [13]. pH value or 
potential hydrogen ions of the wastewater is used to measure the concentration of hydrogen ions $\left(\mathrm{H}^{+}\right)$in the influent wastewater which gives a significant impact on microbial growth rate in a biological treatment process [13]. In a biological treatment process, the irregular $\mathrm{pH}$ value of raw wastewater will significantly decrease the rate of organic compounds removal from the environment, which causes the biological oxygen demand (BOD) measurements to become seriously affected [1]. Temperature is a vital factor that affects the reaction rate during sewage wastewater treatment [13]. Turbidity is an optical property that determines the clarity of water [14]. The water turbidity is influenced by the concentration of total suspended solids and total dissolved solids which come from the soil, sediment, organic matters, and inorganic matters [15]. TSS refers to the total amount of solids that are larger than 2 microns that can be found in the body of the water [16]. COD is a parameter to measure the required amount of oxygen for chemical oxidation during the water treatment process so that carbonaceous organic matter can be decomposed and stabilized $[17,18]$.

Performance evaluation is a piece of fundamental knowledge on functional performance to identify future enhancement of the process [19]. Due to the long period of more than 20 years of the ASHTP operation, it is predicted that failure in the sewage wastewater treatment system, such as failure of mechanical equipment and structures, wastewater overflow, or failure in biological treatment system can take place. [20] Such failure can decrease the performance of the sewage wastewater treatment plant. Therefore, it is important to evaluate the performance of the sewage treatment plant to ensure the treated wastewater meet the standard discharge limits set by the authorities. Furthermore, well-maintenance based on proper evaluation can prolong the lifespan of the plants and avoid any discrepancy between the plants. Thus, this study was carried out to evaluate the performance of both ASHTP used in the UiTM Sarawak Branch. This is to ensure that the performance of the treated effluent discharged is well accepted as well as to maintain the performance condition of the treatment plant.

\section{MATERIAL AND METHODS}

\subsection{Activated Sludge Hi Kleen Treatment Plant (ASHTP) Process Flow}

Figure 1 shows the locations of ASHTP at H Block area and at L Block area in the Universiti Teknologi MARA (UiTM) Sarawak Branch, Samarahan Campus, Sarawak, Malaysia. A ground observation was conducted to evaluate the performance requirement of both ASHTP to ensure its functionality.

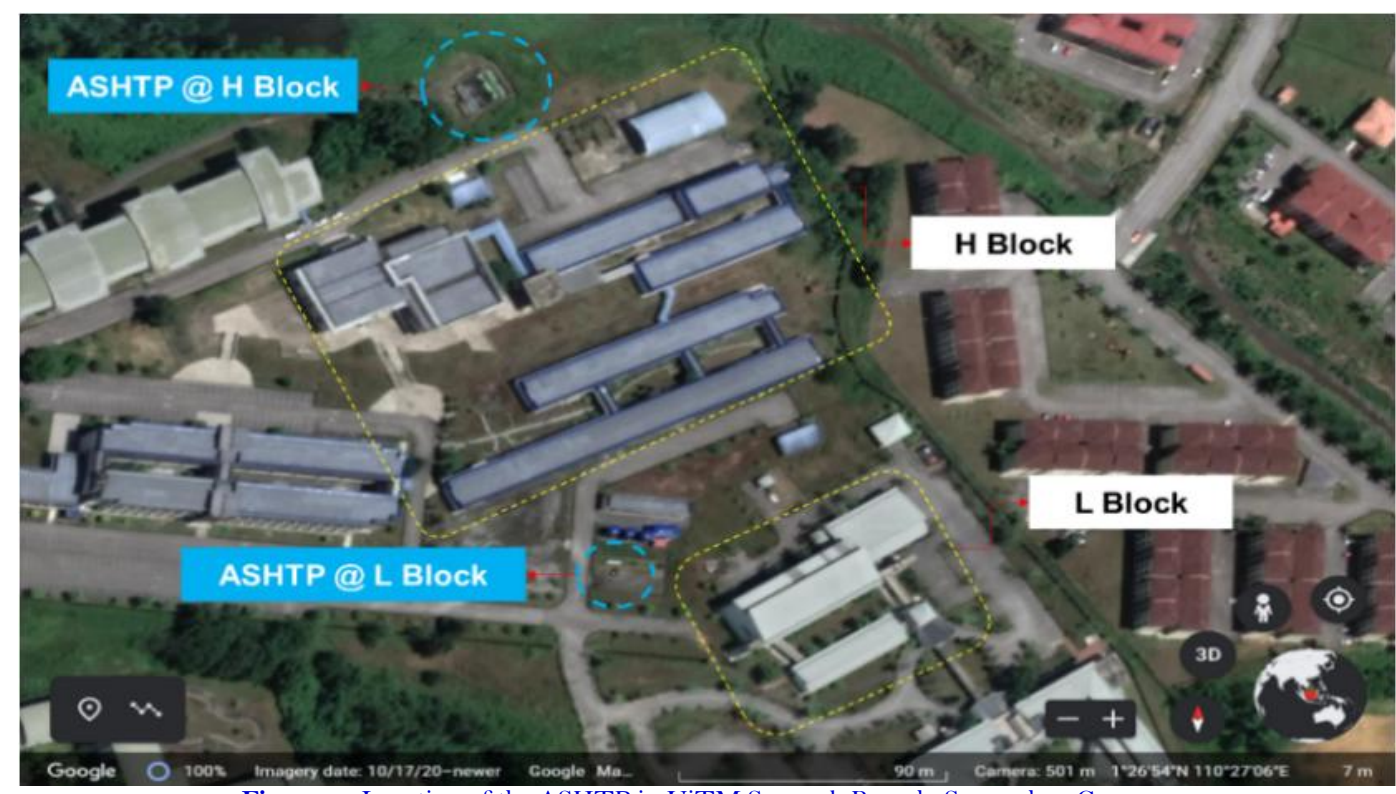

Figure-1. Location of the ASHTP in UiTM Sarawak Branch, Samarahan Campus. 
Figure 2 shows the schematic diagram of the ASHTP process flow which consists of (1) screen chamber, (2) pump sump, (3) equalization tank, (4) aeration tank, (5) clarifier, and (6) sludge concentration tank. For ASHTP at $\mathrm{H}$ Block, sewage wastewater was discharged from the academic units in the H Block area as indicated in Figure 1. As for ASHTP at L Block, sewage wastewater was discharged from the laboratory units in L Block.

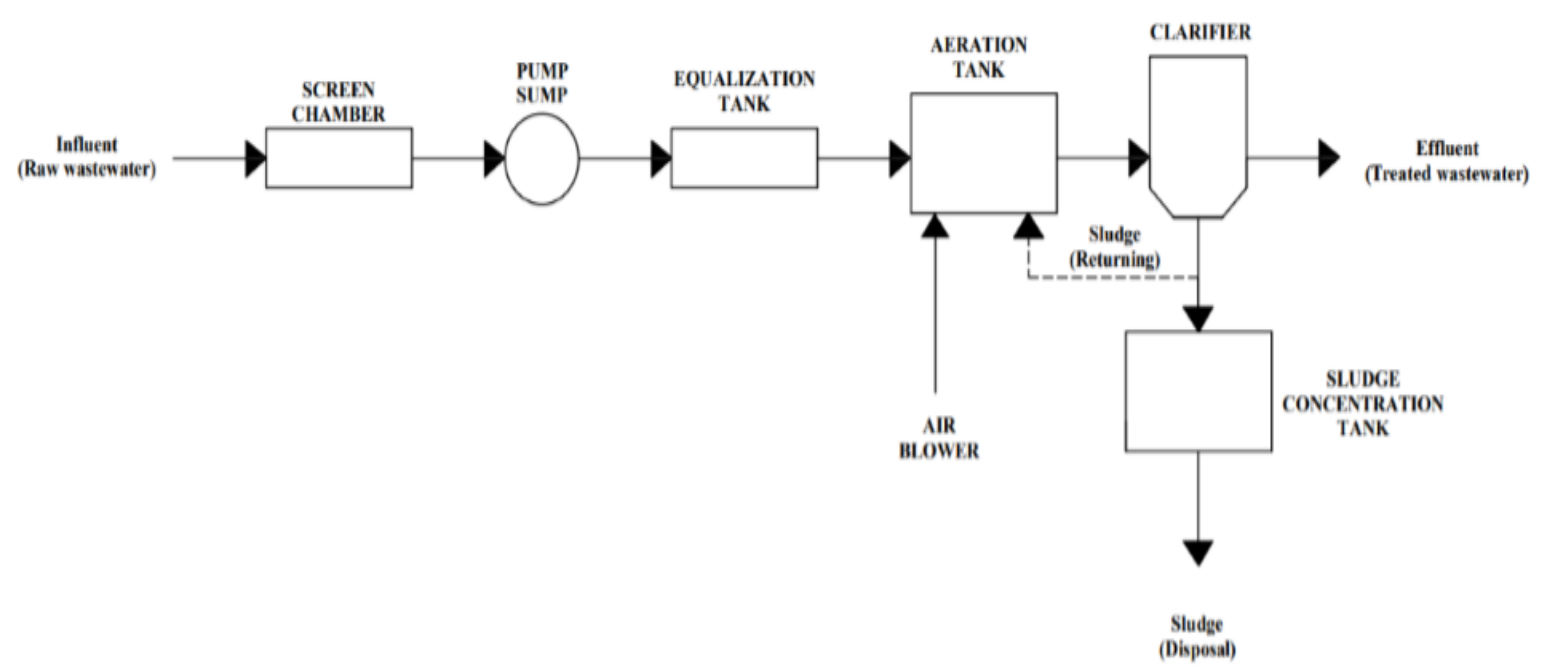

Figure-2. Activated Sludge Hi-Kleen Treatment Plant (ASHTP) process flow.

Primarily, the raw sewage wastewater flowed into the screening chamber, whereby large objects were blocked by the mechanical screen and the water which flowed through it was channeled to the equalization tank by using a mechanical pump sump. The sewage wastewater then flowed into an aeration tank which was connected with two air blowers that supplied oxygen and created an aerobic condition in the aeration tank. As the aeration tank was in aerobic condition, tiny bubbles of oxygen were formed and the organic compound in the wastewater was metabolized. These two air blowers operated alternately and were controlled by using a timer. The aerated sewage wastewater was then siphoned into a clarifier tank in which the treated sewage water was discharged as effluent, whereas heavy pollutants settled at the bottom of the clarifier. From the clarifier, the sludge was collected inside the sludge concentration tank and then was manually disposed.

\subsection{Sewage Wastewater Sampling}

The raw sewage wastewater samples were taken at the screen chamber. The samples were taken in the range of $15-30 \mathrm{~cm}$ below the wastewater surface for analysis. The treated sewage wastewater samples were taken at the effluent discharge which flows from the clarifier. Sampling was done three times in weekly intervals. The samples were collected using a $500 \mathrm{~mL}$ wide-mouth plastic bottle and transferred into $1500 \mathrm{~mL}$ transparent plastic bottles. The samples were then stored at $10-15^{\circ} \mathrm{C}$ before further analysis was carried out. To measure the performance of the ASHTP, the samples were analyzed for pH, TSS, COD, turbidity, and temperature.

\subsection{In-Situ Measurement}

The physical parameters namely; turbidity, temperature, and $\mathrm{pH}$ of the water sample were determined immediately as they can change significantly over time. Baird, et al. [21] before analysis, the instruments used to measure the physical parameters were calibrated and all samples were agitated gently in ensuring a representative measurement. Turbidity was measured using a portable turbidity meter (Hanna Instruments, Malaysia) while pH value was measured using a pH meter (Mettler Toledo, USA). On the other hand, the temperature was measured using a digital thermometer (Alla, France). 


\subsection{Laboratory Analysis}

The laboratory analyses to measure COD, TSS, and turbidity were conducted based on the Standard Methods for the Examination of Water and Wastewater [21].

\subsubsection{Chemical Oxygen Demand (COD)}

The test was carried out based on the US EPA reactor digestion method which applies $\mathrm{HACH}$ spectrophotometer. $100 \mathrm{~mL}$ of water sample was homogenized, and the spectrophotometer was preheated at $150^{\circ} \mathrm{C}$. $2 \mathrm{~mL}$ of water sample was added to the COD digestion reagent vials. A blank sample was prepared using the same method. Both the water sample and blank sample were then heated for 2 hours. Samples inside the vials were cooled for 20 minutes and the vials were inverted several times before measuring the COD of the water.

\subsubsection{Total Suspended Solid}

A filtered paper (Whatman $\mathrm{GF} / \mathrm{F}$ glass fiber filter, nominal pore size, $0.7 \mu \mathrm{m}$ ) was dried in the oven at $100^{\circ} \mathrm{C}$ for $1 \mathrm{~h}$ to remove the moisture content. After $1 \mathrm{~h}$, the mass of the dried filtered paper was recorded. Then, $10 \mathrm{~mL}$ of the water sample was filtered. The residue was desiccated until the changes in the mass of the residue and the filtered paper became constant. The mass obtained was then recorded. TSS in influent and effluent wastewater were determined using Equation 1.

$$
\operatorname{TSS}(m g / L)=\frac{(A-B) \times 1000}{V}
$$

where $\quad$ TSS $=$ total suspended solids $(\mathrm{mg}), \mathrm{A}=$ mass of filter paper + mass of desiccated residue $(\mathrm{mg}), \mathrm{B}=\mathrm{mass}$ weight of initial filter paper $(\mathrm{mg})$, and $\mathrm{V}=$ volume of sample $(10 \mathrm{~mL}=0.01 \mathrm{~L})$.

\subsubsection{Turbidity}

The turbidity of the water samples was analyzed using a turbidity meter (Model: HACH DR900). $15 \mathrm{~mL}$ of water sample was poured into a vial. The vial was then inserted into the turbidity meter and where measurement was taken. The measurement was conducted in triplicates for three different water samples.

\subsection{Removal Efficiency of a Pollutant}

The removal efficiency of COD, TSS and turbidity by the ASHTP was calculated by using Equation 2 [1]:

$$
E(\%)=\frac{C_{o}-C_{e}}{C_{o}} \times 100 \%
$$

where $\mathrm{E}=$ removal efficiency $(\%), \mathrm{C}_{\mathrm{o}}=$ concentration of a specific pollutant in influent $\left(\mathrm{mg} / \mathrm{L}\right.$ or NTU), and $\mathrm{C}_{\mathrm{e}}=$ concentration of a specific pollutant in effluent ( $\mathrm{mg} / \mathrm{L}$ or NTU).

\section{RESULTS AND DISCUSSION}

\subsection{Raw Sewage Wastewater Characteristics}

Table 1 shows the characteristics of the influent samples taken from the screen chambers. All water parameters were compared to Standard B [12]. For ASHTP at H Block, the influent pH, temperature, turbidity, COD, and TSS were found to be $7.4,22.1^{\circ} \mathrm{C}, 74.3 \mathrm{NTU}, 16.35 \mathrm{mg} / \mathrm{L}$, and $74.30 \mathrm{mg} / \mathrm{L}$ respectively. Meanwhile, for ASHTP at L Block, the influent $\mathrm{pH}$, temperature, turbidity, COD, and TSS of raw wastewater were found to be $7.25,28.25^{\circ} \mathrm{C}$, $37.15 \mathrm{NTU}, 100 \mathrm{mg} / \mathrm{L}$, and $37.20 \mathrm{mg} / \mathrm{L}$ respectively. All parameters except turbidity at $\mathrm{H}$ Block and COD at L Block were within the Standard Discharge Limits given by the Department of Environment (DOE) Malaysia. 
Table-1. Characteristics of influent sewage wastewater samples.

\begin{tabular}{l|l|c|c|c}
\hline Parameter & Unit & ASHTP @ H Block & ASHTP @ L Block & Standard Discharge Limits $^{\mathbf{a}}$ \\
\hline $\mathrm{pH}$ & & 7.40 & 7.25 & $5.5-9.0$ \\
\hline Temperature & ${ }^{\circ} \mathrm{C}$ & 22.10 & 28.25 & 40 \\
\hline Turbidity & $\mathrm{NTU}$ & 74.30 & 37.15 & 50 \\
\hline $\mathrm{COD}$ & $\mathrm{mg} / \mathrm{L}$ & 16.35 & 100 & 100 \\
\hline TSS & $\mathrm{mg} / \mathrm{L}$ & 74.30 & 37.20 & 100 \\
\hline
\end{tabular}

\subsection{Performance of Activated Sludge Hi-Kleen Treatment Plant (ASHTP)}

Table 2 shows the overall performance of ASHTP generated at the areas of H Block and L Block. Both ASHTP exhibited their ability to remove pollutants from the sewage wastewater treatment plant, which lead to significant removals in turbidity, COD, and TSS.

Table-2. Characteristics of influent and effluent sewage wastewater at ASHTP at H Block and L Block.

\begin{tabular}{l|c|c|c|c|c|c}
\hline \multirow{2}{*}{ Parameter } & \multirow{2}{*}{ Unit } & \multicolumn{2}{|c|}{$\begin{array}{c}\text { ASHTP Influent } \\
\text { Average }\end{array}$} & \multicolumn{2}{c|}{$\begin{array}{c}\text { ASHTP Effluent Range } \\
\text { (Average) }\end{array}$} & \multirow{2}{*}{$\begin{array}{c}\text { Standard } \\
\text { Limits }^{a}\end{array}$} \\
\cline { 3 - 7 } & & H Block & L Block & H Block & L Block & $5.5-9.0$ \\
\hline $\mathrm{pH}$ & & 7.40 & 7.25 & $7.10-7.80(7.30)$ & $7.20-7.60(7.30)$ & 40 \\
\hline Temperature & ${ }^{\circ} \mathrm{C}$ & 22.10 & 28.25 & $25.45-30.30(28.10)$ & $25.80-28.90(27.90)$ & 50 \\
\hline Turbidity & $\mathrm{NTU}$ & 74.30 & 37.15 & $6.80-16.50(10.40)$ & $12.25-45.35(21.10)$ & 100 \\
\hline COD & $\mathrm{mg} / \mathrm{L}$ & 16.35 & 100 & $12.15-16.00(14.10)$ & $30.75-97.30(58.10)$ & 100 \\
\hline TSS & $\mathrm{mg} / \mathrm{L}$ & 74.30 & 37.20 & $2.15-16.50(8.90)$ & $14.85-22.80(18.00)$ & 100 \\
\hline
\end{tabular}

3.2.1.pH

The $\mathrm{pH}$ values of the sewage wastewater were within the range of $7.1-7.8$ which met the standard discharge limit set by the authority, Malaysia. The changes in $\mathrm{pH}$ value of the treated sewage wastewater are attributed to the decomposition of organic matter. This causes the sewage wastewater to become either acidic or basic, which causes the microbe to have its structure modified and its growth subsequently inhibited. However, some microbes' systems can tolerate changes of $\mathrm{pH}$ in the water and can thrive in the acidic or basic environments of the water [3]. In the ASHTP system, the nitrification process occurs naturally in the aeration tank. During the nitrification process, the $\mathrm{HCO}_{3}-$ level in the water decreases while the $\mathrm{H}_{2} \mathrm{CO}_{3}$ level increases. This led to a decrease in the $\mathrm{pH}$ value of the treated wastewater [1]. The findings indicated that both ASHTP at H Block and ASHTP at L Block have optimum $\mathrm{pH}$ values for the nitrification process that took place in the aeration tanks.

\subsubsection{Temperature}

The temperatures of the influent and effluent at both ASHTP were between 22.1 and $30.3^{\circ} \mathrm{C}$, which were below the maximum permissible limit of $40^{\circ} \mathrm{C}$ as stipulated by the regulation. Malaysia is a tropical country with a stable ambient temperature throughout the year that influences the temperature of both influent and effluent temperature results. In addition, the collection of all water samples took place during sunny days. For a biological process, wastewater temperature is important as microbial growth can be affected by temperature [13]. The biological process by microbes inside the treatment plant can operate at optimum temperatures of $25-35^{\circ} \mathrm{C}$. The rate of the biological activity accelerates as the wastewater temperature becomes warmer, but the activity declines when the wastewater becomes extremely hot or cold [1]. Thus, the temperature of water in ASHTP at H Block and ASHTP at L Block was ideal for wastewater treatment.

\subsubsection{Turbidity}

Substantial removal of turbidity can be seen after the treatment process as shown in Table 2. The average turbidity of sewage wastewater reduced from 74.30 to $10.40 \mathrm{NTU}$ at ASHTP at H Block, while reduction for 
ASHTP at L Block was from 37.15 to 21.10 NTU. This result shows that the turbidity of both effluents was satisfactory as they were below the permissible limit of 50 NTU. In Malaysia, alum is commonly applied in the water treatment plant due to its cost-efficiency [22]. Application of bio-coagulants derived from various types of natural resources is also being used to reduce turbidity and total suspended solids due to their efficiency, abundant source, cheap price, and biodegradability [13]. However, in the ASHTP only aeration was applied which provided the microbes with oxygen for the biological process to take place to reduce pollutants naturally.

\subsubsection{Chemical Oxygen Demand (COD)}

The average COD reduced from 16.35 to $14.10 \mathrm{mg} / \mathrm{L}$ at ASHTP at H Block while for ASHTP at L Block, the reduction was from 100 to $58.10 \mathrm{mg} / \mathrm{L}$. The COD for effluent wastewater at both ASHTP units was below the maximum permissible limit of $100 \mathrm{mg} / \mathrm{L}$. COD measurement is important as it evaluates the effectiveness of the biological treatment process in the sewage treatment system [23]. In the biological treatment, various species of microorganisms such as bacteria, protozoa, and fungi participate in removing the COD and BOD [3, 13]. High effective contact between the microorganisms and the organic matters which reside in the sewage treatment system helps to establish a proper environment and maintain suitable conditions for the microbial life such as temperature, $\mathrm{pH}$, and contact time [1].

\subsubsection{Total Suspended Solids (TSS)}

The average TSS concentration in the influent sewage wastewater entering ASHTP at H Block and ASHTP at $\mathrm{L}$ Block was $74.30 \mathrm{mg} / \mathrm{L}$ and $37.20 \mathrm{mg} / \mathrm{L}$ respectively, which were below $100 \mathrm{mg} / \mathrm{L}$ of the maximum permissible limit. These values were then reduced to $8.90 \mathrm{mg} / \mathrm{L}$ and $18.00 \mathrm{mg} / \mathrm{L}$ at ASHTP at H Block and ASHTP at L Block respectively after the treatment process. These results indicated that ASHTP was functioning properly because the TSS effluent readings were below the standard limit.

\subsection{Removal Efficiency of Physicochemical Parameters}

Sewage treatment plant is required to remove any undesired pollutants from water so the wastewater effluent complies with the required quality or discharge standard, indicating treatment efficiency [1]. Table 3 is the summary of the treatment efficiencies of ASHTP at H Block and ASHTP at L Block in removing turbidity, COD, and TSS. For ASHTP at H Block, turbidity, COD and TSS removal efficiencies were 86.00, 13.76, and 88.02\% whereas for ASHTP at L Block, the removal efficiencies were 43.20, 41.90, and $51.61 \%$ respectively.

In terms of turbidity, the removal efficiency of ASHTP at H Block (86\%) was higher than ASHTP at L Block (43.20\%). For COD concentration, the ASHTP at H Block (13.76\%) has lower COD removal efficiency compared to ASHTP at L Block (41.90\%).

Meanwhile, for TSS removal, the ASHTP at H Block (88.02\%) has higher TSS removal efficiency compared to the ASHTP at L Block (51.61\%). The higher percentage of removal efficiency was due to the higher influent values of the wastewater. Nonetheless, all the effluent values showed compliance with the standard limits. To further improve the turbidity, COD, and TSS removal efficiency, it is suggested that proper maintenance for individual units of ASHTP should be carried out due to prolonged periods of operation that may cause a decline in the performance of ASHTP as an existing sewage treatment plant [13].

Table 4 shows a comparison of the treatment efficiency between the ASHTP used in this study, Extended Aeration Activated Sludge Treatment Plant (EAASTP) and Kashan Wastewater Treatment Plant (KWTP) [2, 24]. EAASTP is also located in Universiti Teknologi MARA Sarawak Branch, Samarahan Campus, Sarawak, Malaysia, whereas Kashan Wastewater Treatment Plant is in Kashan City, Isfahan, Iran. 
Table-3. Performance of ASHTP at H Block and L Block.

\begin{tabular}{l|l|c|c}
\hline \multirow{2}{*}{ Parameter } & \multirow{2}{*}{ Unit } & \multicolumn{2}{|c}{ Removal Efficiency (\%) } \\
\cline { 3 - 4 } & & ASHTP @ H Block & ASHTP @ L Block \\
\hline $\mathrm{pH}$ & & $\mathrm{N} / \mathrm{A}$ & $\mathrm{N} / \mathrm{A}$ \\
\hline Temperature & ${ }^{\circ} \mathrm{C}$ & $\mathrm{N} / \mathrm{A}$ & $\mathrm{N} / \mathrm{A}$ \\
\hline Turbidity & $\mathrm{NTU}$ & 86.00 & 43.20 \\
\hline $\mathrm{COD}$ & $\mathrm{mg} / \mathrm{L}$ & 13.76 & 41.90 \\
\hline TSS & $\mathrm{mg} / \mathrm{L}$ & 88.02 & 51.61 \\
\hline
\end{tabular}

Table-4. A comparison study on different sewage treatment plants.

\begin{tabular}{l|c|c|c|c}
\hline \multirow{2}{*}{ Treatment Plant } & \multicolumn{3}{|c|}{ Removal Efficiency (\%) } & \multirow{2}{*}{ Reference } \\
\cline { 2 - 4 } & Turbidity & COD & TSS & \\
\hline EAASTP & 83.00 & 65.00 & 55.00 & {$[2]$} \\
\hline KWTP & 69.75 & 70.34 & 84.71 & {$[24]$} \\
\hline ASHTP@, H Block & 86.00 & 13.76 & 88.02 & This study \\
\hline ASHTP @, L Block & 43.20 & 41.90 & 51.61 & This study \\
\hline
\end{tabular}

The pollutant in this study was generally removed during the sedimentation process (physical treatment) and aeration process (biological treatment). Climate is one of the major influences in the performance of the biological wastewater treatment process. Whereas Malaysia is a tropical country, ASHTP is a suitable sewage treatment system. The results indicate that the discharged sewage wastewater effluent had optimum $\mathrm{pH}$ and temperature. In addition, the biological treatment in the ASHTP was effective in removing up to $41.90 \%$ of COD, which was lower than the COD removal efficiency for EAASTP and KWTP. COD was removed during the screening and sedimentation process and was further reduced during the aeration process. The highest removal efficiency by ASHTP was reported for turbidity at $86 \%$, which was higher than the turbidity removal efficiency by EAASTP and KWTP. Sedimentation and aeration play major roles in the high removal of turbidity by removing coarse and settleable solids found in the sewage wastewater efficiently. Furthermore, ASHTP removed TSS concentration up to $88.02 \%$, which was higher than both EAASTP and KWTP. In the physical and biological treatment process, 60 to $70 \%$ and 65 to $95 \%$ of total suspended solids will be removed [1]. Findings from this study found that the removal efficiency of TSS was adequate.

There are a few processes that could be recommended to improve the performance of the ASHTP. The removal efficiency could be improved by adding a coagulation process into the sewage treatment system as any type of coagulant can remove COD, TSS, and turbidity at a higher degree [25]. In addition, proper maintenance for each unit must be done to prolong the lifespan of the sewage treatment plant. The purpose of these recommendations is to enhance pollutants removal efficiency and to maintain the good operation of ASHTP in meeting the stipulated standards, which can reduce the negative impacts on human health and the environment.

\section{CONCLUSION}

This evaluation and performance of Activated Sludge Hi-Kleen Treatment Plant (ASHTP) which has operated for more than 20 years and is located at H Block and L Block in UiTM Sarawak (Samarahan Campus) in terms of physicochemical characterization was successfully carried out. The overall performance of ASHTP was found satisfactory and the operation for an individual unit of the sewage treatment process plant functioned well. All selected physicochemical parameters of the treated effluent met Standard B as stipulated in the Environmental Quality (Sewage) Regulations 2009. The removal efficiency of turbidity, COD, and TSS for ASHTP was found to be $43.20-86.00 \%, 13.76-41.90 \%$, and $51.61-88.02 \%$ respectively. Nevertheless, an improvement could be required to enhance the removal efficiency, prolong the lifespan, and maintain the performance of the sewage treatment system, which in turn enables the sewage treatment system to produce wastewater effluent within the acceptable 
range of parameters. For future research, it is recommended to adopt more parameters including biological indicators and green index as new quantitative environmental performance indicators to ensure better assessments of the performance of ASHTP as a sewage treatment plant.

Funding: This study was supported by Dana Kecemerlangan UiTM Sarawak 2018 research grant, Universiti Teknologi MARA (UiTM) Sarawak Branch (600-RMU/DANA/ST 5/3 $(14 / 2018))$.

Competing Interests: The authors declare that they have no competing interests.

Acknowledgement: The authors gratefully acknowledge the Faculty of Chemical Engineering and the Facilities Management of Universiti Teknologi MARA (UiTM) Sarawak Branch for providing the facilities and technical supports.

\section{REFERENCES}

[1] M. Von Sperling, Biological wastewater treatment series: Wastewater characteristics, treatment and disposal vol. 4. London, United Kingdom: IWA Publishing, 2007.

[2] N. Md, J. Idris, K. Mohammad, A. K. Azir, A. Hadi, S. N. Afiqah, M. Ali, N. Athirah, N. Diana, and L. Dundun, "Process design and physicochemical characterization of extended aeration activated sludge treatment plant: A case study," Journal of Asian Scientific Research, vol. 10, pp. 121-130, 2020.Available at: https://doi.org/10.18488/journal.2.2020.103.121.130.

[3] M. Pell and A. Wörman, "Biological wastewater treatment systems, comprehensive biotechnology," ed Amsterdam, Netherlands: Elsevier, 2011.

[4] S. K. Dentel and Y. Qi, "Management of sludges, biosolids, and residuals, in comprehensive water quality and purification," ed Massachusetts, United States of America: Academic Press, 2014, pp. 223-243.

[5] H. K. S. Panahi, M. Dehhaghi, Y. S. Ok, A.-S. Nizami, B. Khoshnevisan, S. I. Mussatto, M. Aghbashlo, M. Tabatabaei, and S. S. Lam, "A comprehensive review of engineered biochar: Production, characteristics, and environmental applications," Journal of Cleaner Production, vol. 270, p. 122462, 2020.Available at: https://doi.org/10.1016/j.jclepro.2020.122462.

[6] R. S. Ramalho, "Pretreatment and primary treatment, in Introduction to Wastewater Treatment Processes," 2nd ed New York, United States of America: Academic Press, 1983, p. 79.

[7] N. L. Nemerow, "Equalization and proportioning, in Industrial Waste Treatment: Contemporary Practice and Vision for the Future," ed Oxford, United Kingdom: Elsevier, 2007, p. 45.

[8] R. S. Ramalho, "Theory and practice of aeration in wastewater treatment, in Introduction to Wastewater Treatment Processes," 2nd ed New York, United States of America: Academic Press Incorporation, 1983, p. 170.

[9] N. Srivastava and J. Chattopadhyay, "Bacterial community structure, composition and their role in biological wastewater treatment reactors plants, in Wastewater Treatment Reactors: Microbial Community Structure, S. Shah, Maulin P.;Rodriguez-Couto, Ed," 1st ed Oxford, United Kingdom: Elsevier, 202 1, pp. 583-597.

[10] S. Smarzewska and K. Morawska, "Wastewater treatment technologies, in Handbook of Advanced Approaches Towards Pollution Prevention and Control: Conventional and Innovative Technology, and Assessment Techniques for Pollution Prevention and Control, C. M. Rahman, Rehab O Abdel; Hussain, Ed." vol. 1, ed Amsterdam, Netherlands: Elsevier, 2021, pp. 3-32.

[11] S. Moran, "Sludge treatment unit operation design: biological processes, in An Applied Guide to Water and Effluent Treatment Plant Design," 1st ed Amsterdam, Netherlands: Elsevier, 2018, pp. 277-287.

[12] DOE, Environmental requirements: A guide for investors, Ministry of Natural Resources and Environment, no. October. Putrajaya: Federal Government Administrative Cente, 2010.

[13] Metcalf and Eddy, "Wastewater engineering: Treatment and resource recovery." vol. 1, 5th ed New York, United States of America: McGraw-Hill, 2014.

[14] J. U. Grobbelaar, "Turbidity, in encyclopaedia of Inland waters," ed Massachusetts, United States of America: Academic Press, 2009, pp. 699-704. 
[15] H. K. Mandal, "Influence of wastewater $\mathrm{pH}$ on turbidity," International Journal of Environmental Research and Development, vol. 4, pp. 105-114, 2014.

[16] Fondriest, "Turbidity, total suspended solids \& water clarity, fundamentals of environmental measurements. Retrieved from https:// www.fondriest.com/environmental-measurements/parameters/water-quality/turbidity-totalsuspended-solids-water-clarity/. [Accessed Aug. 22, 2021]," 2014.

[17] S. K. Jain and V. P. Singh, "Water quality modeling, in Developments in Water Science." vol. 51, ed Amsterdam, Netherlands: Elsevier B.V., 2003, pp. 743-786.

[18] A. R. Abdul Syukor, S. Sulaiman, J. P. Chandrakant, P. Mishra, M. Nasrullah, L. Singh, and A. W. Zularism, "Energy generation from fishprocessing waste using microbial fuel cells, in Delivering Low-Carbon Biofuels with Bioproduct Recovery, Delivering Low-Carbon Biofuels with Bioproduct Recovery: An Integrated Approach to Commercializing Bioelectrochemical Systems," ed Amsterdam, Netherlands: Elsevier, 202 1, pp. 101-121.

[19] M. A. Mustapha, Z. A. Manan, and S. R. W. Alwi, "A new quantitative overall environmental performance indicator for a wastewater treatment plant," Journal of Cleaner Production, vol. 167, pp. 815-823, 2017.Available at: https://doi.org/10.1016/j.jclepro.2017.08.169.

[20] I. Tušer and A. Oulehlová, "Risk assessment and sustainability of wastewater treatment plant operation," Sustainability, vol. 13, pp. 1-17, 2021 .Available at: https://doi.org/10.3390/su 13095120.

[21] R. B. Baird, A. D. Eaton, E. W. Rice, and L. Bridgewater, Standard methods for the examination of water and wastewater vol. 23. Washington, DC: American Public Health Association, 2017.

[22] B. A. Dempsey, "Coagulant characteristics and reactions, in Interface Science in Drinking Water Treatment, G. Newcombe and D. Dixon, Eds," ed Amsterdam, Netherlands: Elsevier Ltd, 2006, pp. 5-24.

[23] Z. Hu and D. Grasso, "Water analysis - chemical oxygen demand, Encyclopaedia of Analytical Science," ed Amsterdam, Netherlands: Elsevier, 2005, pp. 325-330.

[24] R. Dehghani, M. B. Miranzadeh, A. M. Tehrani, H. Akbari, L. Iranshahi, and A. Zeraatkar, "Evaluation of raw wastewater characteristic and effluent quality in Kashan Wastewater Treatment Plant," Membrane Water Treatment, vol. 9, pp. 273-278, 2018.

[25] Environmental Protection Agency, Water treatment manuals: Coagulation, flocculation \& clarification. Wexford, Ireland: An Ghníomhaireacht um Chaomhnú Comhshaoil, 2002.

Views and opinions expressed in this article are the views and opinions of the author(s), Journal of Asian Scientific Research shall not be responsible or answerable for any loss, damage or liability etc. caused in relation to/arising out of the use of the content. 